\title{
On the Occurrence and Damage of the Invasive Nutria (Myocastor coypus Molina, 1782) in Palestine
}

\author{
Abdel Fattah N. Abd Rabou ${ }^{1}$; Mohammed A. Abd Rabou ${ }^{2}$; Abdel Fattah A. Qaraman ${ }^{3}$; Abdallah S. \\ Awad $^{4}$; Yousif K. Ibrahim ${ }^{5}$; Randa N. Alfarra ${ }^{6}$; Sara H. Al-Sweirki ${ }^{1}$; Israa M. Jaber ${ }^{1}$; Hana S. Abu \\ Saada $^{1}$; Kamal J. Elnabris ${ }^{1}$; Kamal E. Elkahlout ${ }^{1}$, Ashraf A. Shafei ${ }^{1}$; Amin M. Wafi ${ }^{7}$; Othman A. Abd \\ Rabou ${ }^{7}$; Asmaa A. Abd Rabou ${ }^{8}$; Huda E. Abu Amra ${ }^{9}$; Ramy A. Abu Alajeen ${ }^{10}$; Norman A. Khalaf ${ }^{11}$; \\ Bashar S. Jarayseh ${ }^{12}$; Daoud I. Al-Hali ${ }^{13}$; Khaled A. Hamode ${ }^{14}$; Hashem A. Madkour ${ }^{15}$; Fatma A. \\ Madkour $^{16}$; Walid F. Mohamed ${ }^{17}$
}

Received: 19 July, 2021, Accepted: 21 Sep, 2021, Published: 1 Oct, 2021

1 Department of Biology and Biotechnology, Islamic University of Gaza, Gaza Strip, Palestine

2 Department of Information Technology, University College of Applied Sciences, Gaza Strip,

Palestine

3 Energy and Environment Research Center, Israa University, Gaza Strip, Palestine

4 Department of Nursing, Faculty of Medical Sciences, Israa University, Gaza Strip, Palestine

5 Water and Environment Quality Authority, Gaza Strip, Palestine

6 Department of Curricula and Teaching Methods, Islamic University of Gaza, Gaza Strip, Palestine

7 Department of Journalism and Media, Islamic University of Gaza, Gaza Strip, Palestine

8 Department of Civil Engineering, Islamic University of Gaza, Gaza Strip, Palestine

9 Department of Biology, Al-Aqsa University, Gaza Strip, Palestine

10 Department of Geography, Al-Aqsa University, Gaza Strip, Palestine

11 Department of Environmental Research and Media, National Research Center, Palestine

12 Environmental Education Center, Beit Jala, West Bank, Palestine

13 Qimmah Secondary School, Al-Quds, Palestine

14 Mshwar Travel, Qlansawa, Palestine

15 National Institute of Oceanography and Fisheries, Hurghada, Egypt

16 Department of Anatomy and Embryology, Veterinary Medicine, South Valley University, Qena, Egypt

17 Department of Biological and Geological Sciences, Faculty of Education, Ain Shams University, Roxy, Cairo, Egypt.

Corresponding Author: Abdel Fattah N. Abd Rabou, arabou@iugaza.edu.ps 


\section{Abstract}

The Nutria or Coypu (Myocastor coypus Molina, 1782) is one of the invasive vertebrate species residing in and near some aquatic habitats of Palestine (27,000 km2) and other neighboring countries. The animal was said to be introduced from Chile, South America, into Palestine by fish farmers for fur production in the early 1950s. It was released into many aquatic ecosystems for economic and ecological reasons, but it was proved to cause damage to agriculture, wildlife and other human properties. Hence, the current descriptive study comes to give notes on the occurrence and dangers of the invasive Nutria in Palestine. The study, which lasted three years (July 2018 - June 2021), was based on many procedures to satisfy its purposes. Frequent field visits, direct observations and photography, meetings and discussions with stakeholders, and fellow-up of local news and social media sites were common tools used throughout the succeeding stages of the study. The current study shows that the Nutria happens in great parts of northern and central and coastal Palestine, including the Hula Lake, the Jordan River and its tributaries, and many valleys of Palestine. Specimens of the animal caught from northern Wadi Arabah and Negev Desert as well. In spite of their polluted waters, Wadi Al-Muqatta in northern Jenin, West Bank, and the lower Jordan River harbor a population the invasive Nutria. The Nutria does not occur in the Gaza Strip and the three live specimens of the animal incidentally fell into fishing nets in 1997 seemed to come from Ashkelon; the closest city in the Palestinian land occupied by Israel since 1948. As far as the dangers of the invasive Nutria in Palestine are concerned, they include herbivory and destruction of aquatic plants, attack and feeding on agricultural crops, creation of "eat-outs" areas which is harmful to many freshwater animals including the Caspian Terrapin (Mauremys caspica), use of and disturbance to many water birds nests, competition with the Eurasian Otter (Lutra lutra), damages of burrowing behavior of Nutria to banks along waterways and other human properties, and aggressiveness towards humans and pets. Many measures have been applied to control the Nutria in Palestine. The role of the Palestinian carnivorous mammals in controlling the Nutria should be respected.

Keywords: Nutria, Myocastor coypus, aquatic habitats, Hula Lake, Jordan River, Wadi Al-Muqatta, dangers, control measures, Palestine. 


\section{Introduction}

Palestine $\left(27,000 \mathrm{~km}^{2}\right)$ harbors more than 100 terrestrial mammalian faunistic species living in diverse ecosystems and habitats extending from north to south and from east to west (Qumsiyeh, 1996). Order Rodentia (rodents) makes up a large part of the Palestinian mammalian fauna because it is considered the largest among the existing mammalian orders worldwide (Boitani and Bartoli, 1983 and Harrison and Bates, 1991). Of the Palestinian rodents, two are considered the largest. The first inhabits several terrestrial environments, including dry and rocky ones, and is called the Indian Crested Porcupine (Hystrix indica Kerr, 1792), while the other, which is invasive (alien, exotic, or non-indigenous), resides in and near water bodies, lakes, wetlands, swamps, ponds, rivers and streams and is called the Nutria (Myocastor coypus Molina, 1782). The Nutria, which belongs to Echimyidae family, has many common or English names such as Coypu or Giant Swamp Rat or River Rat or Beaver Rat (Khalaf, 2022a). The animal is nominated among one of the 100 of the "world's worst invaders" and is considered as a pest for numerous countries where it has been introduced (Bertolino et al., 2005; Bertolino and Genovesi, 2007; Bertolino and Ingegno, 2009). It is one of the largest Palestinian fresh water mammals, beside the Eurasian Otter (Lutra lutra Linnaeus, 1758) as pointed out by Ferguson (2002) and Khalaf (2020 and 2022b). It is a large herbivorous and semi-aquatic rodent that is native to subtropical and temperate South or Latin America, and has since been introduced to other continents such as North America, Europe, Asia and Africa, mainly by fur farmers (Qumsiyeh, 1996). It lives in burrows along with stretches of water, and feeds on stems of riparian plants (Prigioni et al., 2005). In spite of its value as a source of good fur (Saadoun et al., 2006), its destructive digging and feeding habits often bring it into conflict with humans (Moran, 1981 and 2003), and as a result, it was considered in many nations as an invasive and pest species that needs control (Carter and Leonard, 2002; Verbeylen, 2002; Bertolino et al., 2005).

Adult Nutria, usually weighs 4-9 kg, has a body length of 40-60 cm, and a tail of 30 to $45 \mathrm{~cm}$. It has a dark brown coarse outer fur with a soft dense gray under the fur (Boitani and Bartoli, 1983). The animal is distinguished by its large bright orange and 
yellow incisors, and its hind feet are webbed as a requirement for aquatic life. The nipples of female Nutria are high on either side, to allow her young to feed while the female is in the water. Besides its quick breeding biology (Qumsiyeh, 1996), the Nutria consumes large quantities of plants. An individual consumes about $25 \%$ of its body weight daily, and feeds throughout the year. They eat the base of the aboveground stems of plants, often digging into organic soil in search of roots and rhizomes. Nutria inhabits natural and man-made wetlands including freshwater marshes, brackish marshes and rarely salt marshes (Lyon and Milliet, 2000). Nutrias either build their own burrows, or occupy burrows that have been abandoned by beavers and other animals. They are also capable of building floating rafts of vegetation (Lyon and Milliet, 2000).

Worldwide, there was a development of Nutria fur farms in the late 19th and early 20th centuries in many countries. From these farms, Nutria often escaped, or was deliberately released into the wild to provide a game animal or to remove aquatic vegetation (Carter and Leonard, 2002). In Uruguay and other countries, the Nutria has long been used for human food, after being trapped for its fur. Both fur and meat production is now increasing and new fresh, frozen and processed meat products are appearing commercially (Tulley et al., 2000 and Saadoun et al., 2006). In the United States of America (USA), the meat of Nutria was used for dog food products. In many regions of the world, the Nutria has become a pest due to its destruction of aquatic plants, marshes, swamps, and irrigation systems, chewing of man-made materials like wooden house panels, eroding river banks, and displacing native or indigenous animals. From a medical point of view, the Nutria hosts a nematode parasite (Strongyloides myopotami) that can infect the skin of humans, causing dermatitis or "Nutria Itch" similar to strongyloidiasis (Bonilla et al., 2000).

Studies on the biology, parasitology, ecology, and control of the Nutria were diverse and seemed to be extensive worldwide. The occurrence of the invasive Nutria was documented in various locations of the world (Purger and Kristufek, 1991; Özkan, 1999; Baroch et al., 2002; Bounds, 2000; Carter and Leonard, 2002; Murariu and Chisamera, 2004; Bertolino and Genovesi, 2007; Roll et al., 2008 and Adamopoulou and Legakis, 2016). However, the majority of the studies surveyed were found to 
concentrate on the ecology and biology of the Nutria in the ecosystems it inhabits or invades (Gosling et al, 1988; Doncaster and Micol, 1989; Reggiani al., 1995; Taylor and Grace, 1995; Borgnia et al., 2000; D'Adamo et al., 2000; Lyon and Milliet, 2000; Tulley et al., 2000; Bollo et al., 2003; Guichón et al., 2003a and b; Meyer et al., 2005; Prigioni et al., 2005; Corriale et al., 2006; Saadoun et al., 2006; Bertolino and Ingegno, 2009; Gabrey et al., 2009; Nolfo-Clements, 2009; Salsamendi et al., 2009; Bertolino et al., 2011 and 2012; Marini et al., 2011; Robert et al., 2013; Farashi and Najafabadi, 2015; Hong et al., 2015; Gruychev, 2017; Jarnevich et al., 2017; Radoslav et al., 2017; Kawamura et al., 2018; and Kim et al., 2019). Because of its pest status to both wild and agricultural plants in addition to other human properties, and due to its negative impacts on other wildlife species; mainly aquatic species, the Nutria was controlled and eradicated. Accordingly, the studies regarding the control and management of the species seemed to be extensive and intensive. They escalate day by day in most of the countries harboring the invasive Nutria (Evans and Ward, 1967; Norris, 1967; Evans, 1970; Baker and Clark, 1988; Bo et al., 1994; Carter and Leonard, 2002; Verbeylen, 2002; Bertolino et al., 2005; Panzacchi et al., 2007; Bertolino and Viterbi, 2010 and Walther et al., 2011). Based on the previously mentioned studies, it appears that the work on the Nutria began in the late 1960s, after its problem worsened in the countries in which it invaded or settled.

Particular studies on the biology, ecology and control of the Nutria in the Middle East countries seemed to be limited and not extensive. In Israel, the Nutria is one of the invasive mammalian species occupying different aquatic habitats including the Hula Lake Hula and its associated Agmon wetland (Dimentman et al., 2012 and Meiri et al., 2019). The Nutria was introduced into Israel by fish farmers from Chile for fur production in the early 1950s (Bodenheimer, 1958) and for economic reasons they were released into the Jordan River (Roll et al., 2008). According to Mendelssohn and Yom-Tov (1999), the animal was also introduced into fish ponds to control reeds, but it proved to cause damage to fish pond dikes due to its burrowing behavior. The Nutria was mentioned among the vertebrate fauna causing damage to agriculture and plastic irrigation pipes (Moran, 1981 and 2003 and Moran and Keidar, 1993). It was one of a long list of wildlife species poached and hunted by guest Thai workers for food purposes (Yom-Tov, 2003). In the Hashemite Kingdom of Jordan or simply 
Jordan, which is the closest country to Palestine, Khoury et al. (2012) indicated that the Nutria is one of eight mammals introduced into the country from abroad. The Nutria is the only species of introduced mammals that expands its range of distribution and is known to occur in the major permanent water bodies of Jordan (Amr, 2000 and 2012) including the Jordan River (Potts, 2011 and 2018). The animal was monitored along the Jordan, Yarmouk and Zarqa Rivers. Khoury et al. (2012) mentioned that a specimen was brought from the northern mouth of the Dead Sea; a salt lake lying between Palestine and Jordan. In Turkey, Kryštufek and Vohralík (2009) listed the Nutria as one of the main invasive mammals. Özkan (1999) recorded the Nutria in the European part of Turkey. Iliker et al. (2009) studied the C-band patterns of chromosomes of the Nutria and they found that the karyotype of the species is comprised of ( $2 n) 42$ chromosomes.

The Nutria was introduced to Palestine during the 1950s (Mendelssohn and Yom-Tov, 1999). In the West Bank of Palestine, the animal seems to exist in the northern governorate of Jenin in addition to the Jordan River. Faunal surveys in the other governorates of the West Bank have nothing to mention regarding the animal (Qumsiyeh, 2016). In the Gaza Strip, which lies at the southern part of the Palestinian coast along the eastern shore of the Mediterranean basin, no traces or literature confirmed the normal occurrence of the animal. However, many local studies highlighted the accidental occurrence of the animal in one occasion in 1997 (Abd Rabou, 2005 and 2020 and Abd Rabou et al., 2007). Accordingly, the current descriptive study comes to highlight the occurrence and dangers of the invasive Nutria (Myocastor coypus Molina, 1782) in Palestine. The importance of the study comes from the fact that it is the first ecological Palestinian study dealing with this invasive species.

\section{Material and Methods}

\subsection{Palestine}

Palestine $\left(27,000 \mathrm{~km}^{2}\right)$ is a geographic region in Western Asia usually considered to include three political masses: The West Bank, the Gaza Strip and the rest of the Palestinian lands occupied by Israel since 1948 (Figure 1). The West Bank (5,655 
$\mathrm{km}^{2}$ ) is bordered by Jordan and the Dead Sea to the east and by the Palestinian lands occupied by Israel since 1948 to the south, west and north. It is composed of 11 governorates: Nablus, Qalqilya, Tubas, Salfit, Tulkarm, Jenin, Jericho and the Jordan Valley, Ramallah and Al-Bireh, Bethlehem, Hebron, and Jerusalem. The West Bank is nowadays studded with Israeli settlements into which Israeli law is pipelined (UNEP, 2003). The Gaza Strip $\left(365 \mathrm{~km}^{2}\right)$ is a small piece of a coastal land lying in the southern part of the Palestinian coast along the eastern shore of the Mediterranean basin. It is surrounded by the Palestinian lands occupied by Israel since 1948 from the east and north, Egypt to the south and the Mediterranean to the west. It is composed of five governorates: North Gaza, Gaza, Middle, Khan Younis, and Rafah (UNEP, 2003).

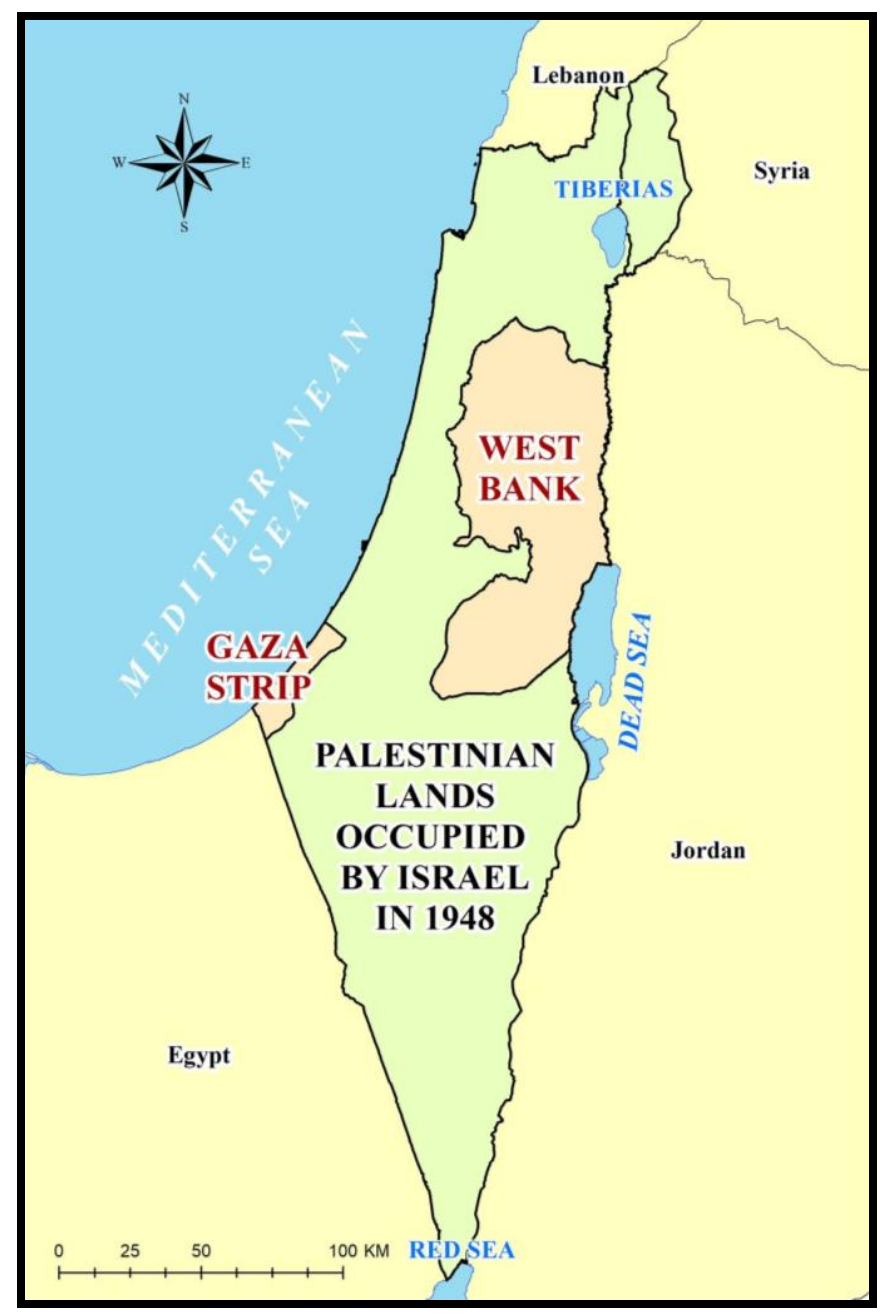

Figure (1): Palestine includes three political masses: The West Bank, the Gaza Strip and the rest of the Palestinian lands occupied by Israel since 1948 
The Gaza Strip has a population of about 2.2 million. The population density is about 5,500 inhabitants per square kilometer, making the Gaza Strip one of the most densely populated areas in the world. All the Israeli settlements that crouched on the land of the Gaza Strip from north to south and from east to west were eradicated, and Israel withdrew from the entire Gaza Strip in late 2005. The majority of the Palestinian Territories that are bordered by Lebanon, Syria, Jordan, the Dead Sea, Egypt, the Red Sea and the Mediterranean Sea, and separate the two Palestinian masses of the West Bank and the Gaza Strip, have been under the occupation of Israel since 1948. So, if someone talks about Palestine, he or she definitely means the entirety of Palestine's $27,000 \mathrm{~km}^{2}$ land that now consists of the West Bank and Gaza Strip in addition to the lands occupied by Israel since 1948 (Figure 1).

The climate of Palestine resembles that of the Mediterranean region which has four months of hot dry summer and a short winter with rain from November to March. The principal water resources in Palestine include groundwater, rivers, lakes, ponds, springs and harvested rainwater. The Jordan River, which is one of the main rivers of Palestine, is about $260 \mathrm{~km}$ long and drains a total area of $18,300 \mathrm{~km}^{2}$ (UNEP, 2003). The river system that composes the Jordan River basin is composed of four tributaries: the Banias, the Hasbani, the Dan and the Yarmouk. The Banias, Hasbani and Dan meet in the northern Palestine to form the Upper Jordan River that flows into Lake Tiberias and the Yarmouk River flows in a southwesterly direction into the Lower Jordan forming the border between Jordan and Syria, the Jordan and Palestine.

The Yarmouk River has a higher flow during the winter periods which is used to dilute the increasing salinity of the Jordan River (UNEP, 2003). The Jordan River and the other rivers, streams, lakes of Palestine are home to a diversity of plant and animal species including the Nutria (Myocastor coypus Molina, 1782); the core axis of the current study.

\subsection{Procedure}

The current study, which lasted three years (July 2018 - June 2021), was based on the following procedures: 
1. Conducting frequent visits, eco-trips, direct observations and monitoring of the Nutria (Myocastor coypus) among other vertebrate fauna occurring in the accessible aquatic habitats and wetland ecosystems of Palestine, some of which are illustrated in Figure 2.

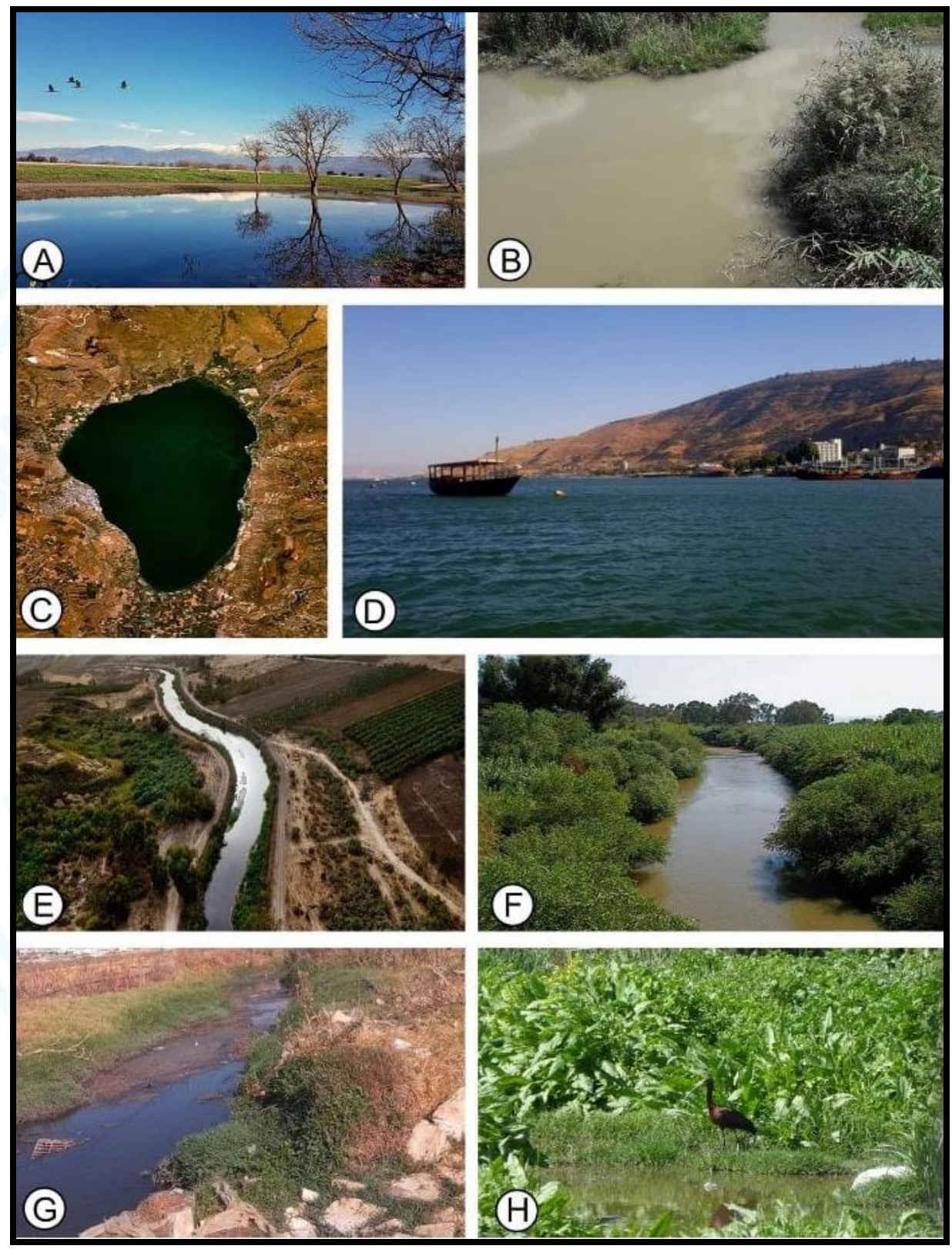

Figure (2): Some of the Palestinian aquatic habitats were commonly monitored for the occurrence of the Nutria and other wildlife species: (A \& B) Hula Lake, (C) A NASA photograph showing the entire Tiberias Lake in North Palestine, (D) Tiberias Lake, (E \& F) Jordan River, which lies between Palestine and Jordan, and (G \& H) Wadi Al-Muqatta in northern Jenin, West Bank, with the Glossy Ibis (Plegadis falcinellus) is commonly seen there. 
2. Carrying out frequent meetings and discussions with local inhabitants, farmers, and wildlife watchers and hunters in order to get more info and to close the gaps regarding the occurrence, ecology and risks of the Nutria in Palestine.

3. Pursuing news and social media sites that are always full of local news related to the diversity of wildlife forms in Palestine, with a special focus on the Nutria, whose presence is concentrated in humid environments and water bodies of Palestine.

4. Using professional binoculars and digital cameras was of an utmost priority throughout the succeeding stages of the current study for documentary and confirmatory purposes.

\section{Results and Discussion}

The Nutria is an invasive or exotic rodent species to the Palestine environment. Local literatures confirmed the introduction of the species 70 years ago from South America for fur production. The escape of many individuals from their breeding nurseries has resulted in the exploding occurrence in vast areas of Palestine, and as a result, the dangers of such occurrence on and in the aquatic habitats and their adjacent ecosystems seem to be considerable. It is worth mentioning that the Nutria is considered to be one of the most damaging invasive species worldwide because of the damage it causes to crops, native flora and fauna and drainage systems (Gosling et al., 1988).

\subsection{Occurrence of Nutria in Palestine}

The Nutria (Myocastor coypus Molina, 1782) is an actual invasive rodent residing in multiple ecosystems and habitats in Palestine (Figure 3). Here, the occurrence of Nutria in Palestine is discussed within three axes: The Palestinian lands occupied by Israel since 1948, the West Bank and the Gaza Strip as follows: 


\subsubsection{Occurrence of Nutria in the Palestinian Lands Occupied by Israel since 1948}

The Nutria was originally introduced from Chile of South America to Palestine for fur farming in 1948 and 1956 (Roll et al., 2008). It seemed that the relatively hot climate of Palestine was not conducive to the growth of the animal's fur for which it was brought in, and therefore the fur farms for the animal failed. Later, some individuals of the Nutria escaped or freed from their breeders to the wild, and their numbers increased dramatically in the Hula Lake and its adjacent swamps in northern Palestine. After then, the Nutria gradually spread from the north of Palestine towards the south. The animal occupied many freshwater environments in Palestine, even some polluted ones. Nowadays, the Nutria is found in great parts of northern and central Palestine, including the Hula Lake, the Jordan River and its tributaries, and many valleys of Palestine (Figures 2 and 3). According to Ferguson (2002), Qumsiyeh (1996) and Khalaf (2022a), the Nutria has become one of the biodiversity components of a lot of humid areas in north and central Palestine including its coastal plain. They added that the animal was found in northern Wadi Araba (Arava Valley) and northern Al-Naqab Desert (Negev Desert). Such additions were not included in the distribution map of the Nutria drawn by Arbel (2008), who concentrated on the occurrence of Nutria in the northern and central parts of the country (Figure 4). According to Meiri et al. (2019), the country hosts bout 130 mammalian species, with Nutrias (Myocastor coypus) and Brown Rats (Rattus norvegicus) are invasive breeders. 
ISRAA UNIVERSITY JOURNAL OF APPLIED SCIENCE

\section{Volume 5 :Issue1, October, 2021}

ISSN: 2523-0522

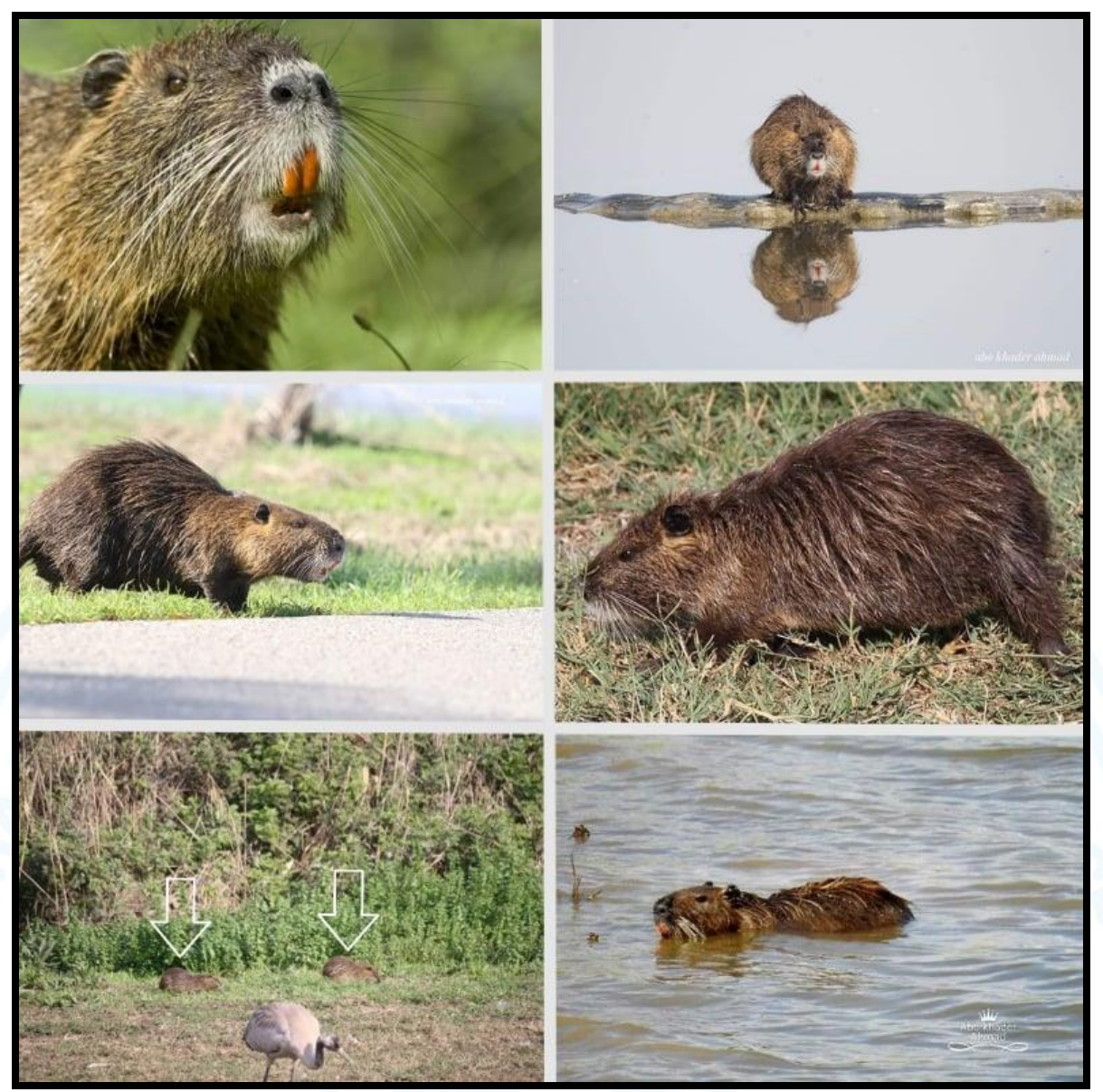

Figure (3): The Nutria was photographed in many Palestinian habitats including the Hula Lake and the Jordan River

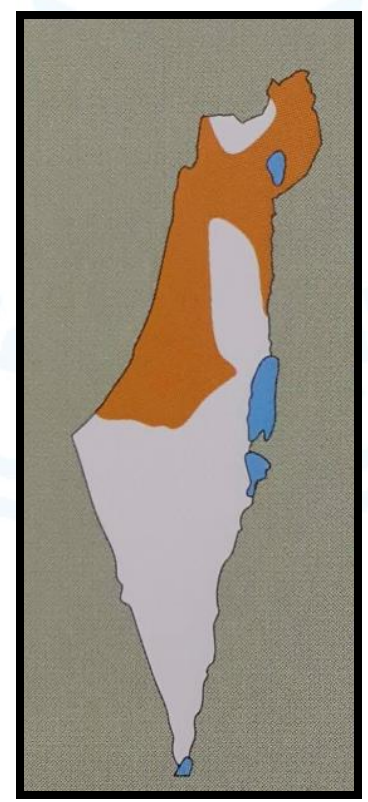

Figure (4): The distribution of the Nutria in Palestine as drawn by Arbel (2008) 


\subsubsection{Occurrence of Nutria in the West Bank, Palestine}

The Nutria seems to inhabit the northern parts of the West Bank represented by Wadi Al-Muqatta or the Jezreel Valley, which is a part of Marj Ibn Amer in Jenin Governorate, and the Jordan River which separates between Palestine and Jordan as pointed out by Atallah (1978), Qumsiyeh and Amr (1999), ARIJ (2007) and Khalaf (2022a). The banks of these two rivers or wadis are densely reeded and the adjacent lands were cultivated with various crops. As a result, they formed good feeding, breeding and resting habitats for the Nutria as well as other wildlife forms. These observations attest to the existence of permanent reproductive population in the two sites of question. Khoury et al. (2012) mentioned that a specimen was brought from the northern mouth of the Dead Sea. No literature confirmed the occurrence of the animal in the other West Bank governorates. This was apparent from various wildlife studies conducted in the West Bank (Qumsiyeh, 2014 and 2016 and Qumsiyeh et al., 2016). Monitoring of juveniles, sub-adults and adults of the Nutria was made easy by many wildlife observers living in the West Bank and in the Palestinian lands occupied by Israel since 1948. Such monitoring confirmed the breeding of the Nutria in the habitats it invaded and settled (Figure 2).

\subsubsection{Jordan River}

The Jordan River or River Jordan or Nahr Al-Shari'ah is a 251-kilometre-long river that flows roughly north to south through the Lake of Tiberias and on to the Dead Sea. Both Jordan and the West Bank take their names from the river. It lies in a structural depression and has the lowest elevation of any river in the world. The valley walls are steep, sheer, and bare, and they are broken only by the gorges of tributary wadis (seasonal watercourses). While the headwaters of the Jordan River are relatively unaffected, the Lower Jordan River consists primarily of untreated wastewater or sewage and agricultural return flows, groundwater seepage, as well as brackish water from springs diverted into the river away from the Lake Tiberias area. The Lower Jordan River in particular is extremely polluted. In spite of this catastrophic environmental situation of the Jordan River, it harbors a diversity of wildlife species including aquatic and terrestrial bird fauna in addition to the Nutria. 
Khoury et al. (2006) and Potts (2011 and 2018) confirmed the occurrence of a great deal of bird fauna in the basin of Jordan River. The upper and lower parts of the Jordan River harbor the Nutria (Myocastor coypus) and the Eurasian Otter (Lutra lutra) as aquatic mammalian species.

\subsubsection{Wadi Al-Muqatta}

Wadi Al-Muqatta or Nahal Qishon in Jenin; northern West Bank is home to beautiful biodiversity components in spite of its environmental tragedies (see Figure 2). The irregular flow of the river or wadi gave rise to the Arabic name "The Cut River" (Nahr Al-Muqatta) (Encyclopedia.com, 2000). The headwaters of Al-Muqatta River start from the hills of Al-Faqqa in northern Palestine near Jenin, and run to the west, penetrating Marj Ibn Amer, then flow intermittently (hence the name) to the northwest until it flows into Haifa Bay. Nowadays, Wadi Al-Muqatta, extends 5.2 km from the city of Jenin to the Israeli Separation Wall, and then extends to the Palestinian Mediterranean coast, is a mix of both fresh water and wastewater coming from the city of Jenin and its camp. It is one of main transboundary streams that convey the discharged wastewater from the West Bank towards the Israeli wastewater treatment plants (WWTPs). The Israelis treat the discharged wastewater on the Palestinians expense and get benefit from the treated wastewater (Ju'ub and Schetelig, 2004 and House of Water and Environment, 2012). In fact, Wastewater from Jenin City and Jenin Camp is collected and partially treated in Jenin WWTP, then flows by gravity through Wadi Al Muqatta towards the Israeli Gilbo' WWTP (House of Water and Environment, 2012). In addition to the wastewater tragedy, Wadi Al-Muqatta is now subject to other environmental problems including cutting and burning of trees and shrubs, overgrazing, discharge of solid waste of multiple categories, as well as changing its course and violating its sanctity. All these practices threaten the ecological integrity of Wadi Al-Muqatta and lead to the loss of much of its biodiversity.

From an ecological point of view, Wadi Al-Muqatta is considered by the local environmental agencies as a biodiversity hot spot in Palestine. In addition to the invasive Nutria, ARIJ (2007) confirmed the occurrence of other mammalian fauna 
including the normally occurring Eurasian Otter (Lutra lutra) and Egyptian Mongoose (Herpestes ichneumon). The Caspian Turtle or Striped-neck Terrapin (Mauremys caspica) is a freshwater reptile that is common as well. The latter seems to occur in most freshwater and polluted rivers and wadis of Palestine including Wadi Gaza, which separates the Gaza Strip into two halves; north and south (MedWetCoast, 2002 and Abd Rabou, 2005). Like other avian studies on wadis and valleys (Khoury,2001; Khoury et al., 2006 and Abd Rabou et al., 2007), recent field studies revealed that Wadi Al-Muqatta is studded with both aquatic and terrestrial avian or bird fauna, some of which were known to be negatively impacted by the invasive Nutria grooming, resting and eating behaviors.

\subsubsection{Occurrence in the Gaza Strip, Palestine}

The Nutria does not occur in the Gaza Strip, and there are no scientific literatures to the natural occurrence of the animal in this piece of Palestine. In a rare and unique incident, three live specimens of the Nutria accidentally fell into fishing nets while fishermen were working in the coastal marine waters of the Gaza Strip in 1997. The strange specimens, which no fishermen were familiar with before, were brought to Palestinian universities, and only one specimen was brought to the Islamic University of Gaza for scientific identification and preservation. The specimen was mummified and preserved at the Biology Department Exhibition at the time (Figure 5). The specimen remained preserved at the Exhibition until the end of 2008, when Israel launched a fierce war on the Gaza Strip and during the war; it bombed the entire scientific laboratory building of the Islamic University of Gaza that housed the Exhibition. The incidental occurrence of the three Nutria specimens in the Gaza Strip in 1997 can be explained by the fact that these individuals entered the Mediterranean Sea from Ashkelon, which is the city closest to the Gaza Strip from the north. In fact, Ashkelon appears to represent the maximum southern occurrence of the Nutria in Palestine as could be deducted from Figure 4 (Arbel, 2008), from where the specimens were brought by sea to Gaza (Abd Rabou, 2005, 2011 and 2020 and Abd Rabou et al., 2007). The Nutria is skilled at swimming (Boitani and Bartoli, 1983). Such skills made the animal travels several kilometers to reach the seawaters of the Gaza Strip and to fall into the Gazan fishing nets. This event may be repeated in the 
next future. The current rehabilitation of Wadi Gaza Nature Reserve and feeding it with treated or semi-treated sewage water coming from nearby sewage treatment plants may pave the way for the undesirable occurrence of this invasive animal in the future.

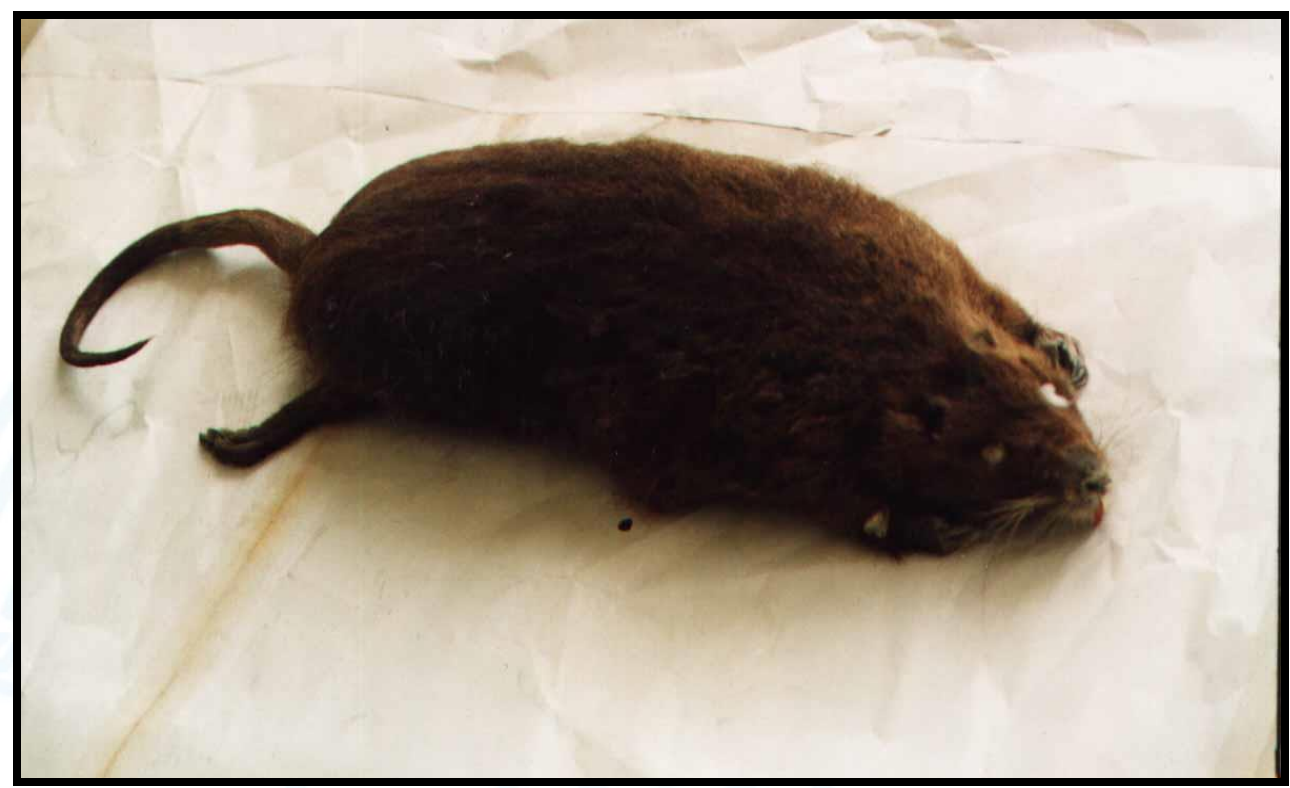

Figure (5): The lonely specimen of the Nutria preserved at the Biology Department Exhibition, Islamic University of Gaza (1997 - 2008)

\subsection{Dangers of the Invasive Nutria in the Palestine Environment}

Nutria damage is evident to varying degrees in every area they are found worldwide. The dangers of the Nutria in the Palestine environment can be explained in the light of the following axes.

\subsubsection{Herbivory and Destruction of Aquatic Plants}

The Nutria is a generalist herbivore; feeding on a wide range of native and non-native aquatic plants and riparian vegetation. It feeds upon the base of the plant stems, meristems, roots, and as a result, these plants are severely damaged. The extensive and intensive grazing of Nutrias leads to local extinctions of aquatic plants which can severely impact wetlands biota structure and function. Reeds; namely the Common Reed (Phragmites australis) and Giant Reed (Arundo donax), are among the most common aquatic, riparian and wetland monostand plants harvested by the Nutria. 
These monocotyledonous plants are commonly preferred by the Nutria as pointed out by Marini et al (2013). In Louisiana, Nutria is known to feed on the roots and rhizomes of many native plant species, and because of this behavior, it is considered wasteful feeder (Linscombe et al., 1981), and estimates suggest that Nutria may waste more than $90 \%$ of the plant material damaged while feeding on the bases of plants. An average of $1,100 \mathrm{~g}$ of vegetation was estimated to be consumed per individual Nutria per day, which amounts to approximately $25 \%$ of individual body mass consumed per day (Taylor et al., 1997 and Link, 2006). Similarly, Nutria can severely damage coastal marshes of USA by decimating native plants that hold marsh soils together and support the survival of native wildlife species (USDA, 2020).

\subsubsection{Feeding on Agricultural Crops}

The Nutria, as previously mentioned, is vegetarian in the sense that it feeds on roots, tubers, shoots, and leaves of plants. Nutria feed on aquatic and semi-aquatic vegetation, but they will venture into crops and gardens to eat a range of vegetables, including corn, sugarcane, beets, cabbage, carrots, potatoes, melons, wheat, alfalfa, clover, soybeans, etc. According to Kuhn and Peloquin (1974), the Nutria attacks and feeds on a variety of native and crop plants such as rice, sugarcane, alfalfa, ryegrass, and fruit and nut trees. In USA, sugarcane and rice are the primary crops damaged by the Nutria. Other crops damaged by the animal include corn, table beets, alfalfa, wheat, barley, oats, peanuts, various melons, and a variety of vegetables (Borgnia et al., 2000). This depredation can lead to significant losses, especially for small farmers (USDA, 2020). Locally, The Nutria has the ability to cause significant economic damage by feeding on the agricultural crops prevailing in its existence areas. Many Palestinian farmers have suffered from the extensive damage to corn and other crops where Nutria inhabits streams and drainage ditches in agricultural lands. In the light of these facts, the Nutria was considered by Palestinian and non-Palestinian farmers as a vertebrate pest that needs control measures. In the vast country, many vertebrate species including mammalian fauna were listed as pests because of their damage to agricultural crops and other human properties (Moran, 1981 and 2003 and Moran and Keidar, 1993). 


\subsubsection{Creation of "Eat-Outs" Areas}

In the Palestinian areas rich in Nutria, the majority of reed and other aquatic plant biomass were subject to extensive removal due to the "eat-outs" behavior of the animal. Such removals result in big patches in the wetland and riparian environments, and as a result, the habitats of biota could be highly disrupted and negatively impacted (Taylor and Grace, 1995 and Link, 2006). Humans are not far a way from such impacts; especially those who are dependent on marshes, swamps and other wetland forms. According to Bertolino et al. (2005), the various activities of the Nutria may pose an indirect threat to marshland birds, reducing the availability of suitable habitats for nesting and breeding. Fish and crabs depend on swamps, marshes and wetlands for shelter and protection from predators and as a source of food can be negatively impacted since the plants and sediments support many insects and other invertebrates.

Jordan River and Hula Lake, as examples, are home to a diversity of freshwater fishes that depend on the biota of these ecosystems to satisfy their feeding, nesting and protection needs (Goren, 1974; Degani et al., 1998; Gophen et al., 1998 and Hamidan, 2004). The loss of these species, in turn, reduces the value of these areas for commercial fisheries and for local ecotourism. The Caspian Terrapin or the Stripenecked Turtle (Mauremys caspica) is a common freshwater turtle present in most freshwater habitats of Palestine including the wadis environments of both the Gaza Strip and the West Bank (Abd Rabou, 2005 and EQA, 2015). This species relies much on the wetland habitats where the Nutria prevails. Destruction of wetlands and their reeds and plants may in a way or another hurt the populations of this unique terrapin (Figure 6).

\subsubsection{Use of and Disturbance to Water Birds Nests}

In the Palestinian aquatic habitats, adults and sub-adults of the Nutria were found to be repeatedly using the nests of water birds (aquatic birds) including ducks and geese (waterfowls) and wading birds (waders) for grooming or resting, eating after their removal of the eggs from the nests. Ecological monitoring carried out in Hula Lake, Jordan River, Wadi Al-Muqatta in northern Jenin, and other parallel environments showed that these habitats support a diversity of both terrestrial and aquatic birds. The 
disturbances of the Nutria to the nests of some water birds were noted as well. The Nutria, in most cases, was found to remove, destroy and sink the eggs of aquatic birds from the nests to be later utilized in the grooming or resting or eating activities. The nests of Eurasian Coots (Fulica atra), Common Moorhens (Gallinula chloropus), Mallards (Anas platyrhynchos) and Black-winged Stilts (Himantopus himantopus) were just examples monitored in Wadi Al-Muqatta and other aquatic habitats in Palestine (Figure 7).

The Black-winged Stilt was found to build its nests on muddy substrates in shallow water bodies in open areas of both Jordan River and Wadi Al-Muqatta. The nesting behavior of the Black-winged Stilt was confirmed by Ashoori (2011) who studied the breeding ecology of the bird in Boujagh National Park, Northern Iran. In fact, there was a considerable disturbance of the Nutria to the local water bird nests either being floating amid the aquatic plants as in the case of Eurasian Coots, Common Moorhens and Mallards or built in the open water as in the case of Black-winged Stilts. It was monitored that the Nutria interfered with brooding birds such as the Black-winged Stilt and used its floating nests as resting sites (Local Observations). Analogous results were revealed by Bertolino et al. (2011) who pointed out that camera surveys confirmed the disturbance caused by the Nutria on the nests of the Eurasian Coot, Common Moorhen, Mallard and Great Crested Grebe (Podiceps cristatus) as common breeding aquatic birds in three Mediterranean wetlands in central Italy. The Nutria used them as resting platforms, thus destroying or sinking the eggs. More or less similar results were obtained by Angelici et al. (2012) who studied the cumulative impacts of Nutria and Norway Rats (Rattus norvegicus) on the nests of waterbirds in Italy as well. 


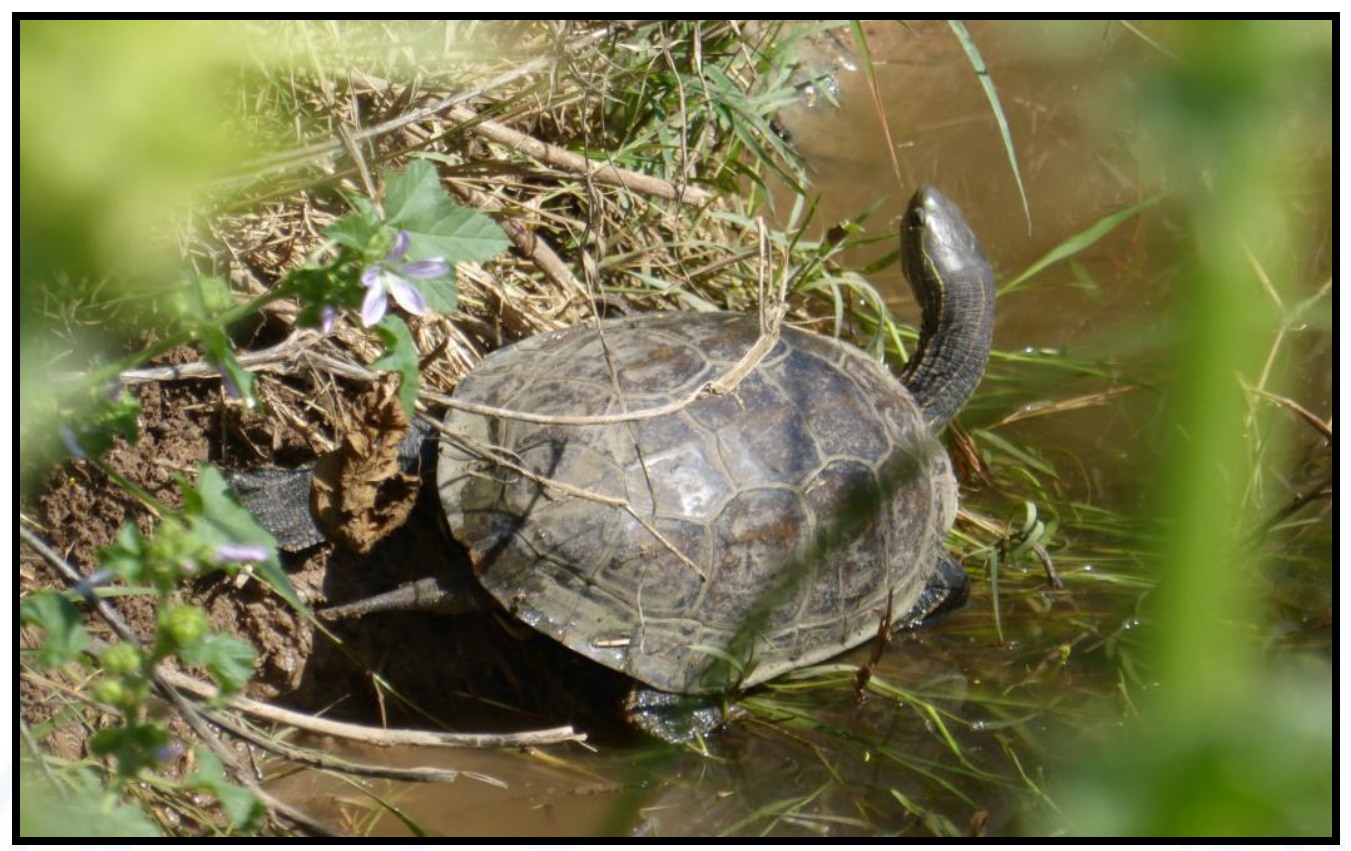

Figure (6): Destruction of wetland habitat by the Nutria may hurt the population of the Caspian Terrapin (Mauremys caspica) [The Photo was taken in Wadi Al-Muqatta, Jenin, North West Bank]

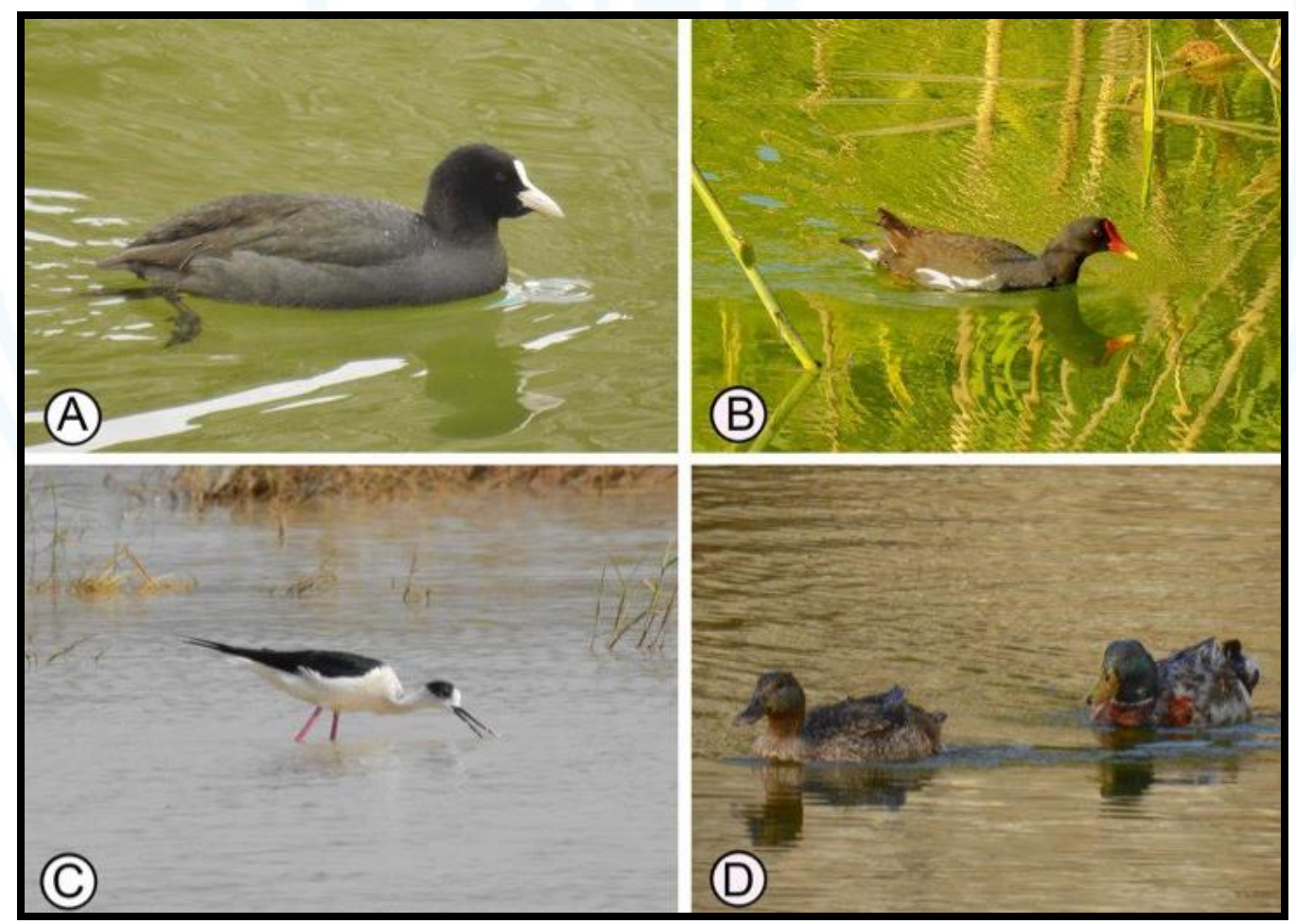

Figure (7): Aquatic birds commonly disturbed by the Nutria in multiple aquatic habitats in

Palestine: (A) Eurasian Coot (Fulica atra), (B) Common Moorhen (Gallinula chloropus), (C) Black-winged Stilt (Himantopus himantopus) and (D) Mallard (Anas platyrhynchos) 


\subsubsection{Competition with the Eurasian Otter (Lutra lutra)}

The Eurasian Otter (Figure 8) is a carnivore (Mustelidae family) that flourishes in the perennial streams of the Palestinian coastal plain, the Jordan River and the streams flowing into the Lake of Tiberias, Hula Lake, and further south towards the Dead Sea (Qumsiyeh, 1996; SPNI, 2015 and Khalaf, 2022b). EQA (2015) pointed out that Wadi Al-Muqatta, northern Jenin, is host to the declining Eurasian Otter among other freshwater wildlife species. The Eurasian Otter seemed not to occur in the Gaza Strip (Abd Rabou et al., 2007 and Abd Rabou, 2009 and 2019), though skeleton remains of the animal were found during excavations done in 1981 in Wadi El-Hesi, North of Gaza District, South-west Palestine (Khalaf, 2020 and 2022b). The population of this animal in Palestine underwent a dramatic decline since the 1960s because of different factors including illegal hunting, roadkills, water pollution, and disappearance of wetland habitats. Recently, the regional status of the Eurasian Otter has been categorized as "Critically Endangered" (SPNI, 2015 and Khalaf, 2022b). The animal feeds upon organisms prevailing in its habitats which include fish, small birds, mammals and invertebrates including insects. It may also feed upon plant material on occasion (Yom-Tov, 1986 and Qumsiyeh, 1996). Khalaf (2022a) pointed out that where the Nutria is established, the endangered Eurasian Otter population is disappearing. Such a fact was confirmed by Eid et al (2020) who pointed out that one of the threats facing the Eurasian Otter in Jordan is its competition with the invasive Nutria. In the past, it was said that some Palestinians might trap and kill the Eurasian Otter instead of the Nutria which is considered as a pest because of its destruction behavior to crops and other vegetation forms. The consumption of the Nutria of about $25 \%$ of its body weight daily on wetland plants (LeBlanc, 1994) may indirectly affect other riparian species inhabiting the West Bank such as the Persian Otter and the Jungle or Swamp or Reed Cat (Felis chaus) as revealed by Khoury et al. (2012). 


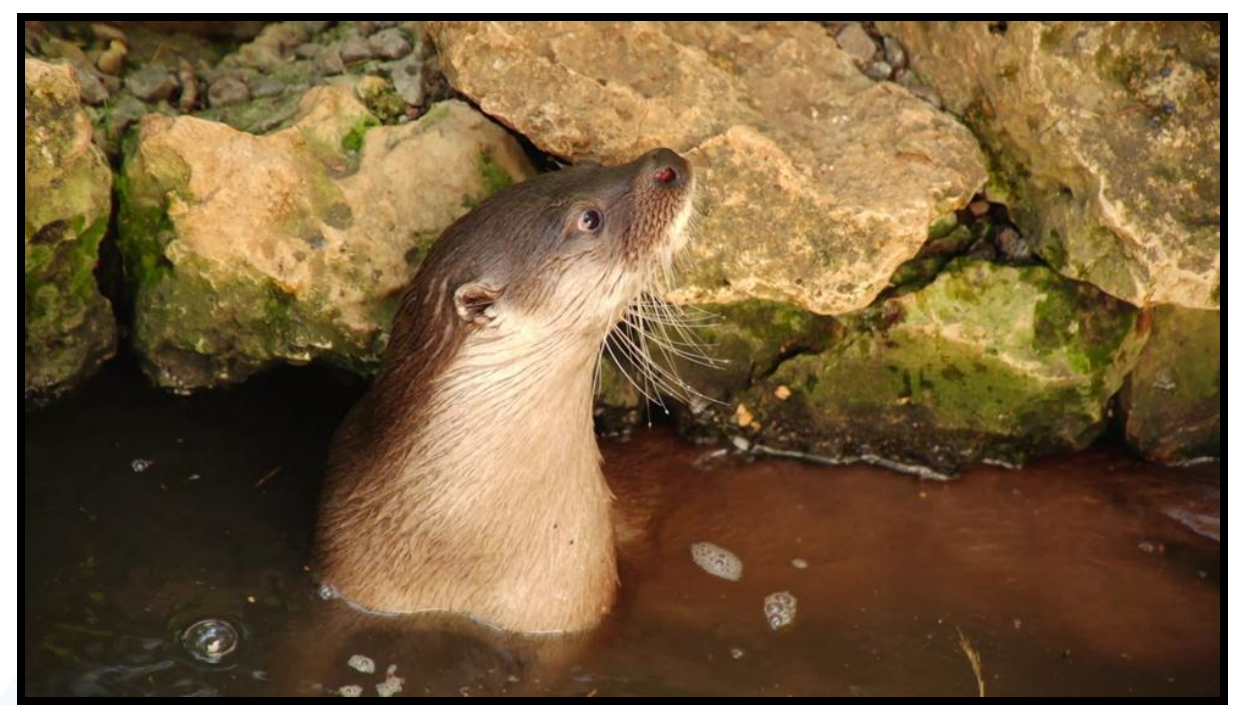

Figure (8): The Eurasian Otter (Lutra lutra) which is now rarely inhabiting the freshwater habitats of Palestine is in an actual competition with the Nutria [Photo was taken by Erez Ehrlichman] https://www.ynetnews.com/business/article/Hk3UI9gX8

\subsubsection{Damages of Burrowing Behavior of Nutria}

The Nutria is avid digger and often digs its own burrows in banks along waterways, streams, rivers and other wetland habitats of Palestine and worldwide. Multiple entrances to a single burrow system are common. The Nutria burrows can damage flood control levees that protect low-lying areas, weaken the foundations of reservoir dams, buildings, embankments and roadbeds; and erode the banks of streams, lakes, and ditches. In Israel, Mendelssohn and Yom-Tov (1999), pointed out that the Nutria was introduced into fish ponds to control reeds because of its vegetarian habit, but it caused much damage to fish pond dikes due to its burrowing behavior. Such impacts cause costly repairs, damage to equipment, and threats to human health and safety. Nutria burrows can undermine the banks of streams and can cause considerable erosion, which can increase sedimentation and decrease water quality. Nutria burrows can cause banks, roadways, and dikes to collapse, threatening the integrity of nearby homes (Link, 2006).

\subsubsection{Pathogen Contamination}

Little information is present in the literature regarding the diseases of the Nutria in the wilderness of Palestine. In other places of the world, the Nutria was known as a 
reservoir of several pathogens and can impact public health and safety. Such diseases and parasites of the Nutria can contaminate drinking water supplies and swimming areas. Many of the water bodies and rivers of Palestine are commonly used in irrigation, recreation and swimming and the presence of Nutrias may cause contamination of these lagoons with parasites in spite of the fact that a great deal of these aquatic habitats are known to be contaminated with pathogenic agents including parasites because of wastewater, agricultural and solid waste disposal. For example, Wadi Al-Muqatta and the lower Jordan River are highly polluted with a variety of pollutants including toxins (EQA, 2015). A lot of studies confirmed that the Nutria is host for Strongyloides myopotami; a nematode parasite that can cause the "nutria itch" or "marsh itch". This parasite can infect the skin of humans and causes dermatitis and severe rashes similar to that of strongyloidiasis (Choe et al., 2014 and USDA, 2020). The Nutria was also found to be a reservoir for the agents causing leptospirosis, toxoplasmosis and other zoonotic diseases (Martino et al., 2014). The Nutria habit of defecating in the water can contaminate it with Giardia and other parasites, including flatworms (Platyhelminthes), roundworms (Nematoda), etc (Dunlap and Thies, 2002; Link, 2006; Zanzani et al., 2016; Kim et al., 2018 and USDA, 2020). It is worth mentioning that strongyloidiasis, giardiasis, amoebiasis, ascariasis, toxoplasmosis and other parasitic diseases are common in Palestine (Nijem and Al-Amleh, 2009; Markovich et al., 2014 and Hamarsheh and Amro, 2020).

\subsubsection{Aggressiveness towards Humans and Pets}

The Nutria is a robust rodent that can reach a weight exceeding 7-8 $\mathrm{kg}$. It can act fiercely, which often brings upon physical harm not only in human beings, but also in pets (animals kept by human beings as a source of companionship and pleasure). Two main pet species are commonly considered in the Palestine urban and rural environments; the Domestic Cat (Felis catus) and the Domestic Dog (Canis familiaris). The inevitable confrontation that sometimes occurs between the Nutria and the pet may lead to injuries and scratches in the bodies of Domestic Cats, Domestic Dogs and other pets. Not only that, but the collapse of the burrows that the Nutria builds near the banks of rivers and streams may cause injuries among the pampered animals, the people who care for them, and the farmers who do their work 
near the areas where the Nutria is present. The large, orange incisors that the Nutria possesses cause fear and terror for the human being who is not used to facing this animal, especially children and women. Gazan fishermen who caught three individuals of the Nutria in 1997 in the Mediterranean waters of the Gaza Strip reported that they were terrified and possessed by fear and panic over the shape of the animal and its orange incisors that they had never seen an animal possessed before (Personal Communications). It is worth mentioning that the teeth of Nutrias have special enamel that includes iron which makes the enamel stronger and also makes the orange color (Srot et al., 2013 and USDA, 2020). The entry of the Nutria to a few homes near Wadi Al-Muqatta in northern Jenin, West Bank, was reported. The Nutria caused fear and terror among children and women, which prompted homeowners to contact the competent authorities, especially the Civil Defense Forces, to deal with the animal, trap and kill it, and remove it from their homes.

\subsection{Control of Nutria}

Live and dead baited traps of various shapes and sizes, firearms, and detection dogs have been applied to systematically seek out and remove the Nutria from infested wetlands and region in Palestine. Leghold or foothold traps, which are indiscriminate, were said to be applied for the same purpose as well. Meanwhile, the high reproduction and dispersal rates of the animal make control methods difficult, costly, and often ineffective (Willner et al., 1979 and Kim, 1980). In many countries worldwide, live baited traps have been placed on floating rafts to effectively catch Nutria (Chapman et al., 1978 and Cocchi and Riga, 2008). In Palestine, it is recommended for farmers and residents to apply several fencing methods to exclude Nutrias from their farms, home gardens and lawns, and the fence must be buried deep in the soil. Moreover, sheet metal shields can effectively protect trees and shrubs from the damage that can result from Nutria attacks. Bulkheads can be used to deter the burrowing of Nutrias into river and wetland banks. Although these control methods can be theoretically and easily suggested, they are very expensive to implement and may not always be available, effective or even practical. In fact, many control measures have been applied in Britain to remove and eradicate the Nutria, some of which demonstrated good results (Gosling, 1981; Gosling and Baker, 1987 and 1989, 
and Gosling et al., 1988). In fact, Palestine is home to many carnivorous mammals which can play as a control agent of environmental vertebrate as well as invertebrate pests including the Nutria. The examples may include the Golden Jackals (Canis aureus), Gray Wolf (Canis lupus), Red Fox (Vulpes vulpes) and the Jungle Cat (Felis chaus). The Domestic Dogs (Canis familiaris) are good predators of the nutria as well. More or less of these Palestinian mammalian fauna were mentioned by many authors to prey on Nutrias worldwide where predators included the Jaguar (Panthera onca), Mountain Lion (Puma concolor), Ocelot (Leopardus pardalis), Little Spotted Cat (Leopardus tigrinus), Red Wolf (Canis rufus), Red Fox (Vulpes vulpes) and Ermine (Mustela erminea) have been reported to consume Nutria regularly (Willner et al., 1979).

\section{ACKNOWLEDGMENT}

The authors extend their sincere thanks and appreciation to all citizens, farmers, photography enthusiasts and media professionals who enriched the current study with valuable information and photographs, without which the study would not have appeared in its present elegant form.

\section{REFERENCES}

Abd Rabou, A.N. (2005): An ecological survey and assessment of Wadi Gaza Nature Reserve, Gaza Strip - Palestine, with particular emphasis on wildlife, [Ph.D. Thesis], Department of Environmental Studies, Faculty of Science and Technology, School of Life Sciences, Al-Neelain University - Sudan, 278 pp.

Abd Rabou, A.N. (2009): On the occurrence of some carnivores in the Gaza Strip, Palestine (Mammalia: Carnivora). Zoology in the Middle East, 46: 109-112.

Abd Rabou, A.N.; Elkahlout, K.E.; Almabhouh, F.A.; Mohamed, W.F.; Khalaf, N.A.; Al-Sadek, M.A.; Alfarra, R.N.; Al-Moqayed, L.T.; Shafei, A.A.; Fayyad, N.A.; Adeem, B.S.; Dardona, A.W.; Awad, A.S.; Al-Agha, M.R. and Abd Rabou, M.A. (2021): Occurrence and some ecological aspects of the Golden 
Jackal (Canis aureus Linnaeus, 1758) in the Gaza Strip, Palestine. Open Journal of Ecology (OJE), 11(2); 105-125.

Abd Rabou, A.N. (2019): The mammalian, reptilian and amphibian fauna of AlMawasi ecosystem, south-western Gaza Strip - Palestine. Agricultural Research \& Technology: Open Access Journal, 23(1): 00301-00314.

Abd Rabou, A.N. (2020): The Palestinian marine and terrestrial vertebrate fauna preserved at the Biology Exhibition, Islamic University of Gaza, bombarded by the Israeli Army in December, 2008. Israa University Journal of Applied Science (IUGAS), 4(1): 9-51.

Abd Rabou, A.N.; Musallam, N.J.; Musallam, E.J.; Elkahlout, K.E.; Elnabris, K.J.; El-Bashiti, T.A.; Abdel Aziz, I.I; Ishneiwra, R.M.; Radwan, E.S.; Saada, H.S.; Shafei, A.A.; Fayyad, N.A.; Mwafy, S.N.; Abu Amra, H.E.; Abu Al-Ajeen, R.A.; Abu Owda, M.F.; Alfarra, R.N.; Hassouna, H.A.; Hassouna, R.A.; AlAgha, M.R. and Abd Rabou, M.A. (2020): The Palestinian terrestrial vertebrate fauna preserved at the biology exhibitions of the universities of the Gaza Strip. Research in Ecology, 2(4): 9-21.

Abd Rabou, A.N.; Yassin, M.M.; Al-Agha, M.R.; Hamad, D.M. and Ali, A.S. (2007): Wild mammals in the Gaza Strip, with particular reference to Wadi Gaza. The Islamic University Journal (Series of Natural Studies and Engineering), 15(1): 87-109.

Adamopoulou, C. and Legakis, A. (2016): First account on the occurrence of selected invasive alien vertebrates in Greece. BioInvasions Records, 5: 189-196.

Amr, Z.S. (2000): Mammals of Jordan. United Nations Environment Program (UNEP). Amman. 116 pp.

Amr, Z.S. (2012): Mammals of Jordan. 2nd Edition. Al Rai Press. Amman, 308 pp.

Amr, Z.S.; Abu Baker, M. and Rifai, L. (2004): Mammals of Jordan. Denisia, 14: 437-465. 
Angelici, C.; Marini, F.; Battisti, C.; Bertolino, S.; Capizzi, D. and Monaco, A. (2012): Cumulative impact of rats and Coypu on nesting waterbirds: First evidences from a small Mediterranean wetland (Central Italy). Vie et Milieu, 62(3):137-141.

Arbel, A. (2008): MAP's dictionary of Mammalia. MAPA Publishers, Tel Aviv, Israel, 438 pp., (In Hebrew).

ARIJ (2007): Status of the environment in the occupied Palestinian Territory. Applied Research Institute - Jerusalem (ARIJ), Swiss Agency for Development and Cooperation (SDC), 223 pp., https://www.arij.org/files/admin/2007_Status_of_Environment.pdf.

Ashoori, A. (2011): Breeding Ecology of the Black-winged Stilt (Himantopus himantopus) in Boujagh National Park, Gilan Province, Northern Iran. Podoces, 6(1): 87-89.

Atallah, S.I. (1978): Mammals of the Eastern Mediterranean region: Their ecology, systematics and zoogeographical relationships. Säugetierkundliche Mitteilungen, 26: 1-50.

Baroch, J.; Hafner, M.S.; Brown, T.L.; Mach, J. and Poché, R.M. (2002): Nutria (Myocastor coypus) in Louisiana. Genesis Laboratories, Inc, Wellington, Colorado, $155 \mathrm{pp}$.

Baker, S.J. and Clarke, C.N. (1988): Cage trapping Coypus (Myocastor coypus) on baited rafts. Journal of Applied Ecology, 25: 41-48.

Bertolino, S.; Perrone A. and Gola, L. (2005): Effectiveness of Coypu control in small Italian wetland areas. Wildlife Society Bulletin, 33: 714-720.

Bertolino, S. and Genovesi, P. (2007): Semi-aquatic mammals introduced into Italy: Case studies in biological invasion. In: Gherardi, F. (ed.): Biological invaders in inland waters: profiles, distribution, and threats. Springer, Dordrecht, The Netherlands, pp. 175-191. 
Bertolino, S. and Ingegno, B. (2009): Modeling the distribution of an introduced species: The Coypu Myocastor coypus (Mammalia, Rodentia) in Piedmont region, NW Italy. Italian Journal of Zoology, 76: 340-346.

Bertolino, S. and Viterbi, R. (2010): Long-term cost-effectiveness of Coypu Myocastor coypus control in Piedmont Italy. Biological Invasions, 12: 25492558.

Bertolino, S.; Angelici, C.; Monaco, E.; Monaco, A. and Capizzi, D. (2011): Is the Coypu (Myocastor coypus) a nest predator or a nest destroyer? Hystrix (Italian Journal of Mammalogy), 22: 333-339.

Bertolino, S.; Angelici, C.; Monaco, E.; Monaco, A. and Capizzi, D. (2012): Interactions between Coypu (Myocastor coypus) and bird nests in three Mediterranean wetlands of central Italy. Hystrix, (Italian Journal of Mammalogy), 22(2): 333-339.

Bodenheimer, F.S. (1958): The present taxonomic status of the terrestrial mammals of Palestine. Bulletin of the Research Council of Israel, 7b: 165-190.

Bo, R.F.; Palomares, F.; Beltrán, J.F.; de Villafañe, G. and Moreno, S. (1994): Immobilization of Coypus (Myocastor coypus) with ketamine hydrochloride and xylazine hydrochloride. Journal of Wildlife Diseases, 30: 596-598.

Boitani, L. and Bartoli, S. (1983): Simon and Schuster's guide to mammals. Simon and Schuster Inc., $511 \mathrm{pp}$.

Bollo, E.; Pregel, P.; Gennero, S.; Pizzoni, E.; Rosati, S.; Nebbia, P.; and Biolatti, B. (2003): Health status of a population of Nutria (Myocastor coypus) living in a protected area in Italy. Research in Veterinary Science, 75: 21-25.

Bonilla, H.; Blanchard, D. and Sanders, R. (2000). Nutria itch. Archives of Dermatology. 136 (6): 804-805. 
Borgnia, M.; Galante M.L. and Cassini M.H. (2000): Diet of the Coypu Myocastor coypus in agro-systems of the Argentinean Pampas. Journal of Wildlife Management. 64: 354-361.

Bounds, D.L. (2000): Nutria: An invasive species of national concern. Wetland Journal, 12: 9-16.

Carter, J. and Leonard, B.P. (2002): A review of the literature on the worldwide distribution, spread of, and efforts to eradicate the Coypu (Myocastor coypus). Wildlife Society Bulletin, 30: 162-175.

Chapman, J.A.; Willner, G.R.; Dixon, K.R. and Pursley, D. (1978): Differential survival rates among leg-trapped and live-trapped Nutria. Journal of Wildlife Management, 42: 926-928.

Choe, S.; Lee, D.; Park, H.; Oh, M.; Jeon, H. and Eom, K.S. (2014): Strongyloides myopotami (Secernentea: Strongyloididae) from the intestine of feral Nutrias (Myocastor coypus) in Korea. Korean Journal of Parasitology, 52(5): 531535.

Cocchi, R. and Riga, F. (2008): Control of a Coypu Myocastor coypus population in northern Italy and management implications. Italian Journal of Zoology, 75: $37-42$

Corriale, M.J.; Arias, S.M.; Bó, R.F. and Porini, G. (2006): Habitat-use patterns of the Coypu Myocastor coypus in an urban wetland of its original distribution. Acta Theriologica, 51(3): 295-302.

D’Adamo, P.; Guichón, M.L.; Bó, R.F. and Cassini, M.H. (2000): Habitat use of the Coypu Myocastor coypus in agrosystems of the Argentinean Pampas. Acta Theriologica, 45: 25-33.

Degani, G.; Yehuda, Y.; Jackson, J. and Gophen, M. (1998): Temporal variation in fish community structure in a newly created wetland lake (Lake Agmon) in Israel. Wetland Ecology and Management, 6: 151-157. 
Dimentman, C.: Bromley, H.J. and Por, F.D. (1992): Lake Hula: Reconstruction of the fauna and hydrobiology of a lost lake. The Israel Academy of Science and Humanities, Jerusalem, 170 pp.

Doncaster, C.P. and Micol, T. (1989): Annual cycle of a Coypu (Myocastor coypus) population: Male and female strategies. Journal of Zoology, 217: 227-240.

Dunlap, B.G. and Thies, M.L. (2002): Giardia in Beaver (Castor canadensis) and Nutria (Myocastor coypus) from east Texas. Journal of Parasitology, 88(6):1254-1258.

Eid, E.; Abu Baker, M. and Amr, Z. (2020): National Red data book of mammals in Jordan. Amman, Jordan: IUCN Regional Office for West Asia Amman, 122 pp.

Encyclopedia.com (2000): Nahal Qishon (Nahr Al-Muqatta). https://www.encyclopedia.com/religion/encyclopedias-almanacs-transcriptsand-maps/kishon.

EQA - Environment Quality Authority (2015): State of Palestine Fifth National Report to the Convection on Biological Diversity (CBD) 2015. $110 \mathrm{pp}$. https://www.cbd.int/doc/world/ps/ps-nr-05-en.pdf.

Evans, J. (1970): About Nutria and their control. U.S. Fish and Wildlife Service, Resource Publication, No. 86. 65 pp.

Evans, J. and Ward, A. L. (1967): Secondary poisoning associated with anticoagulantkilled Nutria. Journal of American Veterinary Medical Association, 151: 856861.

Farashi, A. and Najafabadi, M.S. (2015): Modeling the spread of invasive Nutrias (Myocastor coypus) over Iran. Ecological Complexity, 22: 59-64.

Ferguson, W.W. (2002): The mammals of Israel. Gefen Publishing House, Jerusalem and New York, $160 \mathrm{pp}$. 
Gabrey, S.W., Kinler, N. and Elsey, R.M. (2009): Impacts of Nutria removal on food habits of American Alligators in Louisiana. Southeastern Naturalist, 8: 347354.

Gophen, M.; Yehuda, Y.; Malinkov, A. and Degani, J. (1998): Food composition of the fish community in Lake Agmon. Hydrobiologia, 380: 49-57.

Goren, M. (1974): The freshwater fish of Israel. Israel Journal of Zoology, 23: 67118.

Gosling, L.M. (1981): The effect of cold weather on success in trapping feral Coypus (Myocastor coypus). Journal of Applied Ecology, 18: 467-470.

Gosling, L.M., and Baker, S.J. (1987): Planning and monitoring an attempt to eradicate coypus from Britain. Symposium of the Zoological Society of London, 58: 99-113.

Gosling, L.M., and Baker, S.J. (1989): The eradication of Muskrats and Coypus from Britain. Biological Journal of the Linnean Society. 38: 39-51.

Gosling, L.M.; Baker, S.J. and Clarke, C.N. (1988): An attempt to remove Coypus (Myocastor coypus) from a wetland habitat in East Anglia. Journal of Applied Ecology, 25: 49-62.

Gruychev, G. (2017): Distribution and density of Coypu (Myocastor coypus Molina, 1782) in downstream of Maritsa River, Southeast Bulgaria. Forestry Ideas, 23(1): 77-81.

Guichón, M.L.; Doncaster, C.P. and Cassini, M.H. (2003a): Population structure of Coypus (Myocastor coypus) in their region of origin and comparison with introduced populations. Journal of Zoology, 261: 265-272.

Guichón, M.L.; Benitez, V.; Abba, A.; Borgnia, M. and Cassini, M.H. (2003b): Foraging behavior of Coypus Myocastor coypus: Why do Coypus consume aquatic plants? Acta Oecologica, 24: 241-246. 
Hamarsheh, O. and Amro, A. (2020): Epidemiology of Parasitic Infections in the West Bank and Gaza Strip, Palestine. American Journal of Tropical Medicine and Hygiene, 102(2): 313-317.

Hamidan, N. (2004): The freshwater fish fauna of Jordan. Denisia, 14(2): 385-394.

Harrison, D.L. and Bates, P.J.J. (1991): The mammals of Arabia. Harrison Zoological Museum, Kent, England, 354 pp.

Hong, S.; Do, Y.; Kim, J.Y.; Kim, D.K. and Joo, G.J. (2015): Distribution, spread and habitat preferences of Nutria (Myocastor coypus) invading the lower Nakdong River, South Korea. Biological Invasions, 17: 1485-1496.

House of Water \& Environment - HWE (2012): Understanding and analyzing the current Israeli wastewater practices for transboundary wastewater management from Palestinian: Final report. Austrian Development Cooperation (ADC) \& Palestinian Water Authority (PWA), 74 pp. https://procurement-notices.undp.org/view_file.cfm?doc_id=27195.

Iliker, A.; Arslan, A.; Pamukoğlu, N. and Albayrak, I. (2009): C-banded karyotype of Myocastor coypus (Molina, 1782) from Turkey (Mammalia: Rodentia). Folia Biologica, 57(1-2): 33-36.

Kawamura, K.; Kaieda, S.; Kato, M. and Kobayashi, S. (2018): Invasion genetics of Nutria (Myocastor coypus) in Okayama, Japan, inferred from mitochondrial and microsatellite markers. European Journal of Wildlife Research, 64, 1-13, https://doi.org/10.1007/s10344-018-1185-y.

Khalaf, N.A. (2020): A historical record of the Persian Otter (Lutra lutra seistanica Birula, 1912) from Wadi El-Hesi, North of Gaza Strip, State of Palestine. Gazelle: The Palestinian Biological Bulletin, 38(190): 54-70.

Khalaf, N.A. (2022a): The Coypu, Nutria or the Giant Swamp Rat (Myocastor coypus Molina, 1782) in Palestine. Gazelle: The Palestinian Biological Bulletin, 40 (208): 1-33. 
Khalaf, N.A. (2022b): The Persian Otter (Lutra lutra seistanica Birula, 1912) in Palestine. Gazelle: The Palestinian Biological Bulletin, 40(207): 1-22.

Khoury, F. (2001): On the breeding bird community of Wadi Al-Kharrar, Jordan. Zoology in the Middle East, 22(1): 37-44.

Khoury, F.; Al-Omari, K.; Azar, J. and Al-Hasani, I. (2006): Observations on the avifauna of the eastern Jordan Valley, during July-August 2005. Sandgrouse, 28(2): 119-126.

Khoury, F.; Amr, Z.S.; Hamidan, N.; Al Hassani, I.; Mir, S.; Eid, E. and Bolad, N. (2012): Some introduced vertebrate species to the Hashemite Kingdom of Jordan. Vertebrate Zoology, 62(3): 435-451.

Kim, H.S.; Kong, J.Y.; Kim, J.H.; Yeon, S.C. and Hong, I.H. (2018): A case of Fascioliasis in a wild Nutria, Myocastor coypus, in Republic of Korea. Korean Journal of Parasitology, 56(4): 375-378.

Kim, P. (1980): The Coypu (Myocastor coypus) in the Netherlands: Reproduction, home range and manner of seeking food. Lutra, 23: 55-64.

Kim, Y.; Kim, A.; Lim, J.; Kim, T.; Park, S.; Kim, M.; Lee, J.; Ro Lee; J. and Lee, D. (2019): Distribution and management of Nutria (Myocastor coypus) populations in South Korea. Sustainability, 11, 4169; Doi: $10.3390 /$ su11154169.

Kryštufek, B. and Vohralík, V. (2009): Mammals of Turkey and Cyprus: Rodentia II: Cricetinae, Muridae, Spalacidae, Calomyscidae, Capromyidae, Hystricidae, Castoridae. : Univerza na Primorskem, Znanstveno-raziskovalno središče, Založba Annales: Zgodovinsko društvo za južno Primorsko, 372 pp.

Kuhn, L.W. and Peloquin, E.P. (1974): Oregon's Nutria problem. Proceedings Vertebrate Pest Conference, 6: 101-105. 
LeBlanc, D.J. (1994): Nutria. In: Prevention and Control of Wildlife Damage. Cooperative Extension Division Institute of Agriculture and Natural Resources and USDA APHIS Animal Damage Control, B71-B80.

Link, R. (2006): Living with wildlife: Nutria. Washington Department of Fish and Wildlife, USA, 7 pp. https://wdfw.wa.gov/sites/default/files/publications/00624/dfw00624.pdf.

Linscombe, G.; Kinler, N. and Wright, V. (1981): Nutria population density and vegetative changes in brackish marsh in coastal Louisiana. Pages 129-141 in (Chapman, J.A. and Pursley, D. eds.): Proceedings of the Worldwide Furbearer Conference 1:1-651.

Lyon, W.J. and Milliet, J.B. (2000): Microbial flora associated with Louisiana processed frozen and fresh Nutria (Myocastor coypus) carcasses. Journal of Food Science, 65(6): 1041-1045.

Jarnevich, C.; Young, N.; Sheffels, T.; Carter, J.; Sytsma, M. and Talbert, C. (2017): Evaluating simplistic methods to understand current distributions and forecast distribution changes under climate change scenarios: An example with Coypu (Myocastor coypus). NeoBiota, 32: 107-125.

Ju'ub, G.A. and Schetelig, K. (2004): Surface Water in Jenin GovernoratePalestine. In: Zereini, F., Jaeschke, W. (eds.): Water in the Middle East and in North Africa. Springer, Berlin, Heidelberg. https://doi.org/10.1007/9783-662-10866-6 7.

Marini, F.; Ceccobelli, S. and Battisti, C. (2011): Coypu (Myocastor coypus) in a Mediterranean remnant wetland: A pilot study of a yearly cycle with management implications. Wetlands Ecology and Management, 19: 159-164.

Marini, F.; Gabrielli, E.; Montaudo, L.; Vecchi, M.; Santoro, R.; Battisti, C and Carpaneto, G.M. (2013): Diet of coypu (Myocastor coypus) in a Mediterranean coastal wetland: A possible impact on threatened rushbeds? Vie et milieu - Life and environment, 2013, 63 (2): 97-103 
Markovich, M.P.; Shohat, T.; Riklis, I.; Avni, R.; Yujelevski-Rozenblit, D.; Bassal, R.; Cohen, D. and Rorman, E. (2014): Seroepidemiology of Toxoplasma gondii infection in the Israeli population. Epidemiology and Infection, 142(1): 149-155.

Martino, P.E.; Stanchi, N.O.; Silvestrini, M.; Brihuega, B.; Samartino, L. and Parrado, F. (2014): Seroprevalence for selected pathogens of zoonotic importance in wild Nutria (Myocastor coypus). European Journal of Wildlife Research, 60: $551-554$.

MedWetCoast (2002): Management plan: Wadi Gaza. Project for the Conservation of Wetland and Coastal Ecosystems in the Mediterranean Region MedWetCoast, $171 \mathrm{pp}$.

Meiri, S.; Belmaker, A.; Berkowic, D.; Kazes, K.; Maza, E.; Bar-Oz, G. and Dor, R. (2019): A checklist of Israeli land vertebrates. Israel Journal of Ecology and Evolution, 65(1-2): 43-70.

Mendelssohn, H. and Yom-Tov, Y. (1999): Mammalia of Israel. Israel Academy of Sciences and Humanities, Jerusalem, 439 pp.

Meyer, J.; Klemann, N. and Halle, S. (2005): Diurnal activity patterns of Coypu in an urban habitat. Acta Theriologica, 50(2): 207-211.

Moran, S. (1981): Damage by vertebrates to plastic irrigation pipes in Israel. Phytoparasitica, 9: 211-216.

Moran, S. (2003): Checklist of vertebrate damage to agriculture in Israel, updated for 1993-2001. Phytoparasitica, 31(2):109-117.

Moran, S. and Keidar, H. (1993): Checklist of vertebrate damage to agriculture in Israel. Crop Protection, 12:173-182.

Murariu, D. and Chişamera, G.B. (2004): Myocastor coypus Molina, 1782 (Mammalia: Rodentia: Myocastoridae): A new report along the Danube River 
in Romania. Travaux du Meséum National d'Histoire Naturelle "Grigore Antipa", 46: 281-287.

Nijem, K.I. and Al-Amleh, S. (2009): Seroprevalence and associated risk factors of toxoplasmosis in pregnant women in Hebron District, Palestine. Eastern Mediterranean Health Journal (EMHJ), 15(5): 1278-1284.

Nolfo-Clements, L.E. (2009): Nutria survivorship, movement patterns, and home ranges. Southeastern Naturalist, 8: 399-410.

Norris, J.D. (1967): A campaign against feral Copus (Myocastor coypus Molina) in Great Britain. Journal of Applied Ecology, 4: 191-199.

Özkan, B. (1999): Invasive Coypus, Myocastor coypus (Molina, 1782), in the European part of Turkey. Israel Journal of Zoology, 45(2): 289-291.

Panzacchi, M.; Bertolino, S.; Cocchi, R. and Genovesi, P. (2007): Cost/benefit analysis of two opposite approaches to pest species management: Permanent control of Myocastor coypus in Italy versus eradication in East Anglia UK. Wildlife Biology, 13: 159-171.

Potts, D. (2011): Mammals of the Jordan River. Jordan River Commission, http://jordanrivercommission.com/wp-content/uploads/2011/04/Mammals-ofthe-Jordan-River-2011.pdf.

Potts, D. (2018): Fauna of the Jordan River, https://slcfga.org/images/pdfsdoc/JordanR_Fauna_PDF_8-18.pdf.

Prigioni, C.; Balestrieri, A. and Remonti, L. (2005): Food habits of the Coypu (Myocastor coypus) and its impact on aquatic vegetation in a freshwater habitat of NW Italy. Folia Zoologica, 54: 269-277.

Purger, J.J. and Kristufek, B. (1991): Feral Coypu Myocastor coypus (Rodentia, Mammalia) in Yugoslavia. Biol vestn, 39: 19-24. 
Qumsiyeh M.B. (1996): Mammals of the Holy Land. Texas Tech. University Press, U.S.A., 389 pp.

Qumsiyeh, M.B. (2016): Fauna of Wadi Al-Quff Protected Area: Amphibians, reptiles and mammals. Jordan Journal of Natural History, 3: 70-79.

Qumsiyeh M.B. and Amr, Z.S. (1999): Environmental conservation and protected areas in Palestine: Challenges and opportunities. Hanns Seidel Foundation in Jerusalem, Palestine, $92 \quad$ pp., https://www.mahmiyat.ps/uploads/171013\%20HSF_Bethlehem_Printed\%20V ersion_NC.pdf.

Radoslav, M.; Rosen, D.; Rumen, B. and Kamelia, S. (2017): A study of some biological, anatomical and related environmental features of Nutria (Myocastor coypus) from the territory of Stara Zagora region. Mehmet Akif Ersoy Üniversitesi Veteriner Fakültesi Dergisi, 2(1): 7-15.

Reggiani, G.; Boitani, L. and De Stefano, R. (1995): Population dynamics and regulation in the Coypu Myocastor coypus in central Italy. Ecography, 18:138146.

Robert, H.; Lafontaine, R.; Beudels-Jamar, R.C.; Delsinne, T. and Baiwy, E. (2013): Risk analysis of the Coypu Myocastor coypus (Molina, 1792): Risk analysis report of non-native organisms in Belgium. Royal Belgian Institute of Natural Sciences, DO - 10.13140/RG.2.2.33552.20484.

Roll, U.; Dayan, T. and Simberloff, D. (2008): Non-indigenous terrestrial vertebrates in Israel and adjacent areas. Biological Invasions, 10: 659-672.

Saadoun, A.; Cabrera, M.C. and Castellucio, P. (2006): Fatty acids, cholesterol and protein content of Nutria (Myocastor coypus) meat from an intensive production system in Uruguay. Meat Science, 72: 778-784. 
Salsamendi, E.; Latierro, L. and O'Brien, J. (2009): Current distribution of the Coypu (Myocastor coypus) in the Basque Autonomous Community, northern Iberian Peninsula. Hystrix, the Italian Journal of Mammalogy, 20(2): 155-160.

SPNI - The Society for the Protection of Nature in Israel (2015): A wake-up call to save the common otters. https://natureisrael.-org/News/A-wake-up-call-tosave-the-common-otters.

Srot, V.; Salzberger, U.; Bussmann, B.; Jelenko, I. and van Aken, B.A. (2013): Linkage between microstructure and chemical composition of iron-rich hard dental tissues from the Feral Coypu by analytical TEM investigations. Microscopy and Microanalysis, 19(S2): 188-189.

Taylor, K.L. and Grace, J.B. (1995): The effects of vertebrate herbivory on plant community structure in the coastal marshes of the Pearl River, Louisiana, U.S.A., Wetlands, 15: 68-73.

Taylor, K.L.; Grace, J.B. and Marx, B.D. (1997): The effects of herbivory on neighbor interactions along a coastal marsh gradient. American Journal of Botany, 84: 709-715.

Tulley, R.T.; Malekian, F.M.; Rood, J.C.; Lamb, M.B.; Champagne, C.M.; Redmann, S.M.; Patrick, R.; Kinler, N. and Raby, C.T. (2000): Analysis of the nutritional content of Myocastor coypus. Journal of Food Composition and Analysis, 13(2): 117-125.

Verbeylen, G, (2002): Coypus Myocastor coypus in Flanders: How urgent is their control? Lutra, 45: 83-96.

UNEP (2003): Desk study on the environment in the Occupied Palestinian Territories. United Nations Environment Program (UNEP), Nairobi, Kenya, 188 pp.

USDA - United States Department of Agriculture (2020): Nutria: An invasive rodent (fact sheet). https://www.aphis.usda.gov/publications/wildlife_damage-/fscnutria-invasive-rodent.pdf. 
Walther, B.; Lehmann, M. and Fuelling, O. (2011): Approaches to deal with the Coypu (Myocastor coypus) in urban areas: An example of practice in southern Brandenburg, Germany. JuliusKühn-Archiv, 432: 36-37.

Willner, G.R.; Chapman, J.A., and Pursley, D. (1979): Reproduction, physiological responses, food habitats, and abundance of Nutria on Maryland marshes. Wildlife Monographs, 65: 1-43.

Yom-Tov, Y. (1986): Otters between extinction and survival. Israel - Land and Nature. 11(4): 167-169.Yom-Tov, Y. (2003): Poaching of Israeli wildlife by guest workers. Biological Conservation, 110: 11-20.

Zanzani S.A.; Di Cerbo, A.; Gazzonis, A.L.; Epis, S.; Invernizzi, A.; Tagliabue, S. and Manfredi, M.T. (2016): Parasitic and bacterial infections of Myocastor coypus in a metropolitan area of northwestern Italy. Journal of Wildlife Diseases, 52(1): 126-130. 